\title{
19. On the Tuffaceous Conglomerate at Northwestern Part of Koike in the Sakawa Basin, Shikoku, Japan*)
}

\author{
By Sumio SaKagami and Katsumi Ueno \\ Department of Earth Sciences, Faculty of Science, Chiba University \\ (Communicated by Teiichi Kobayashi, M. J. A., March 12, 1987)
}

Although T. Kobayashi (1950) stated briefly on the tuffaceous conglomerate containing corals (Yatsengia? sp. and Chaetetes bocki) in the limestone pebbles, exposed at the northwestern part of Koike in the Sakawa basin, Kochi Prefecture of Shikoku, the detailed description has not been published. We had a chance to visit the old quarry located at the northwestern part of Koike, ca. $650 \mathrm{~m}$ north of Sakawa Station and collected some rock samples there (see Fig. 1). The present paper deals with the Carboniferous fauna such as fusulines, smaller foraminifers and bryozoans found in the limestone pebbles of the tuffaceous conglomerate.

According to the explanatory text of the geological map of Sakawa town edited by Katto (1982), the Takaoka Formation of the Jurassic complex, which is composed mainly of sandstone and shale with exotic blocks of limestone and chert, is distributed in this area. The exposure of the tuffaceous conglomerate is about $15 \mathrm{~m}$ wide and $5 \mathrm{~m}$ high. Small red chert lenses (ca. $1 \mathrm{~m}$ long and 30 to $40 \mathrm{~cm}$ thick) are intercalated in the conglomerate member. Small conodont fauna including Diplognathodus lanceolatus Igo, D. sp. cf. D. oertlii Kozur and Hindeodus minutus (Ellison), which indicates early Middle Permian in age (see Fig. 2), is extracted from these chert lenses. The contact between the tuffaceous conglomerate member and the surrounding sediments is not observed.

The tuffaceous conglomerate is composed mainly of limestone pebbles in association with the pebbles of basalt and dolerite. Weak lamination is partly developed. The limestone pebbles consist mainly of oosparite and pelmicrite, but micrite, biolithite and pisosparite are also included. It is notable that the calcareous pisolites measure up to $6 \mathrm{~mm}$ in maximum diameter. These pebbles are angular to subangular but occasionally round in shape and $0.2 \mathrm{~cm}$ to $5 \mathrm{~cm}$ in size. Matrix is cemented by highly calcareous tuff.

The fossil remains were found only in the limestone pebbles, but could not be found in the matrix. The following species were discriminated in the limestone pebbles (see Fig. 3).

Fusulines: Eostaffella akiyoshiensis Sada, E. etoi Ota, Millerella sp. cf. $M$. marblensis Thompson, Pseudonovella carbonica (Grozdilova \& Lebedeva), Ozawainella mosquensis Rauser-Chernoussova, O. angulata (Colani), Nankinella sp., Eoschubertella toriyamai Ishii, E. obscula (Lee \& Chen), E. lata (Lee \& Chen), Fusulinella minutissima Ishii, $F$. pygmaea Ishii, $F$. elegantula Ishii, $F$. bocki (Möller), $F$. sp. cf. F. simplicata Toriyama, Fusulina sp. cf. F. kanmerai Ishii, $F$. sp. cf. $F$. shikokuensis Ishii, Beedeina higoensis (Kanmera), B. lanceolata (Lee \& Chen), B. sp.

*) Studies of Japanese Trilobites and Associated Fossils-45. 
SMALlER Foraminifers: Calcisphaera spp., Earlandia sp., Tuberitina bulbacea Galloway \& Harlton, Diplosphaerina sp., Eotuberitina sp., Neotuberitina sp., Climacammina spp., Tetrataxis sp., Globivalvulina sp., Endothyra ex gr. bowmani Phillips emend. Brady, E. spp., Omphalotis sp. cf. O. samarica (Rauser-Chernoussova), Bradyina spp., Eolasiodiscus spp., Brunsia sp.

BryozoAns: Fistulipora sp., Meekoporella sp., Streblascopora sp., Girtypora sp. cf. G. sakagamii Sugimura, Fenestella sp., Penniretepora sp.

Among these taxa, fusuline fauna is most important in consideration of the geological age. It can be recognized three groups showing different ages, but all of them indicates Carboniferous in age.

The first group is represented by Eostaffella aliyoshiensis Sada, Millerella cf. marblensis Thompson and Pseudonovella carbonica (Grozdilova \& Levedeva). E. akiyoshiensis Sada was originally described from the Millerella zone of Akiyoshi Limestone Group, which is correlated with the Serpukhovian. In the Akiyoshi Limestone Group, it is known that E. akiyoshiensis Sada ranges up to the Profusulinella beppensis zone of the Upper Bashkirian. In the present fauna, however, the typical Bashkirian elements such as Pseudostaffella and Profusulinella are not found. Accordingly it is highly probable that the provenance of the limestone pebbles is lacking in the Bashkirian age. From the above mentioned facts, the geological age of this fusuline group is estimated as the Serpukhovian.

The second group is characterized by several species of Fusulinella, Fusulina and Eoschubertella. Among them, Fusulinella pygmaea Ishii, F. minutissima Ishii and Eoschubertella obscula (Lee \& Chen) are dominant. This fauna is very close to that of the Itadorigawa Group, especially of the $\mathrm{It}_{2}$ zone, in western Shikoku reported by Ishii $(1958,1961,1962)$. The Itadorigawa Group is characterized by Fusulina, Eoschubertella, Fusiella and rather primitive Fusulinella, and is correlated with the Lower Moscovian. It may correspond to the lower part of Fusulinella zone in Japan. It is noteworthy that Eostaffella etoi Ota occurs in association with the typical Itadorigawa elements of Fusulinella and Fusulina. E. etoi Ota has been known from the Millerella yowarensis zone to the middle part of the Profusulinella beppensis zone in the Akiyoshi Limestone Group. Therefore the stratigraphic range of $E$. etoi Ota may extend to the lower part of Fusulinella zone.

The third group includes Beedeina higoensis (Kanmera), B. lanceolata (Lee $\&$ Chen), B. sp. and Ozawainella mosquensis Rauser-Chernoussova. Among these fusulines, $B$. higoensis (Kanmera) and $B$. lanceolata (Lee \& Chen) are important as an age indicator of the Late Moscovian, the Beedeina zone.

The smaller foraminiferal fauna from the pebbles is compatible with the fusuline data in consideration of the geological age.

All of the bryozoan genera are known also from the Carboniferous part of the Akiyoshi Limestone Group. Unfortunately the specific name of these bryozoans cannot be given because of the poor and fragmentary specimens, but Girtypora sp. seems to be very close to G. sakagamii Sugimura (1985) which was described from the Profusulinella beppensis zone of the Akiyoshi Limestone Group.

In conclusion, the present fauna in the limestone pebbles of the tuffaceous conglomerate indicates the Serpukhovian to Late Moscovian in Carboniferous age, although the typical Bashkirian fusuline element is lacking. Moreover the 
post-Upper Carboniferous fusulines are not obtained at all.

Recently, Isozaki (1985) restudied the Yasuba conglomerates in his Shingai Formation in the northern subbelt of the Chichibu Belt in central Shikoku. According to him, the conglomerates are revealed to be exotic in origin, and it can be classified into three types: Type I, Type II and Type III. He estimated that the conglomerate Types I and III, poor in terrigenous coarse clastics, are inferred to be sediment-gravity-flow deposits which were essentially accumulated at the base-of-slope along the outskirt of ancient seamount whose top was capped by organic reef or carbonate mound, and the Type II, rich in terrigenous materials, is supposed to have deposited in some area adjacent to ancient Kurosegawa land (arc or microcontinent). From the viewpoints of its lithology and fossils contained, the present tuffaceous conglomerate closely resembles the limestone conglomerate of Inomine located at ca. $5.5 \mathrm{~km}$ northeast of Koike, which was reported as a type of the Yasuba conglomerates containing the Moscovian fusulines in the limestone pebbles by Toriyama (1945), and the conglomerate Type I by Isozaki (1985). It can be estimated that this tuffaceous

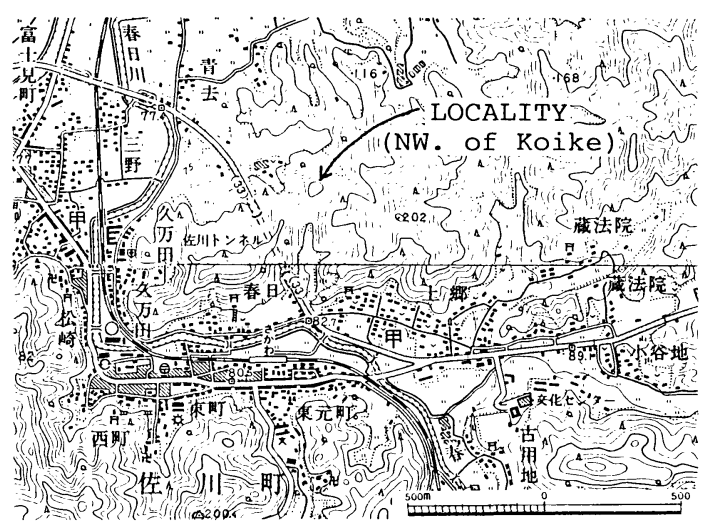

Fig. 1. Map showing the locality of the tuffaceous conglomerate.

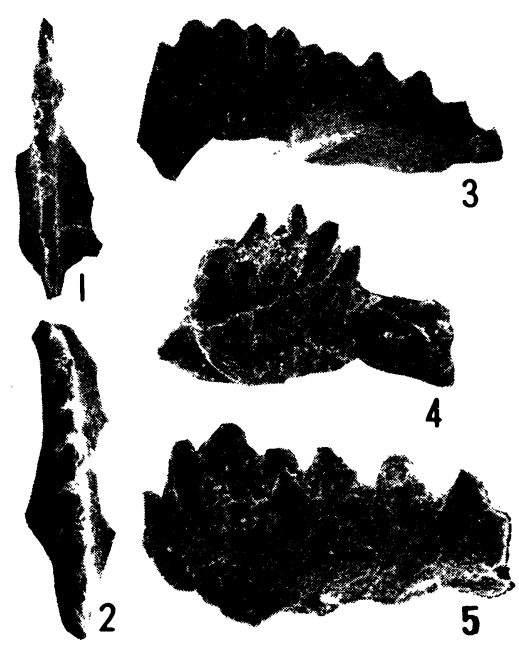

Fig. 2. The Permian conodonts from the chert lens. 1, 2: Diplognathodus lanceolatus Igo. 3, 4: Diplognathodus sp. cf. D. oertlii Kozur. 5: Hindeodus minutus (Ellison). All are in $\times 10$. 


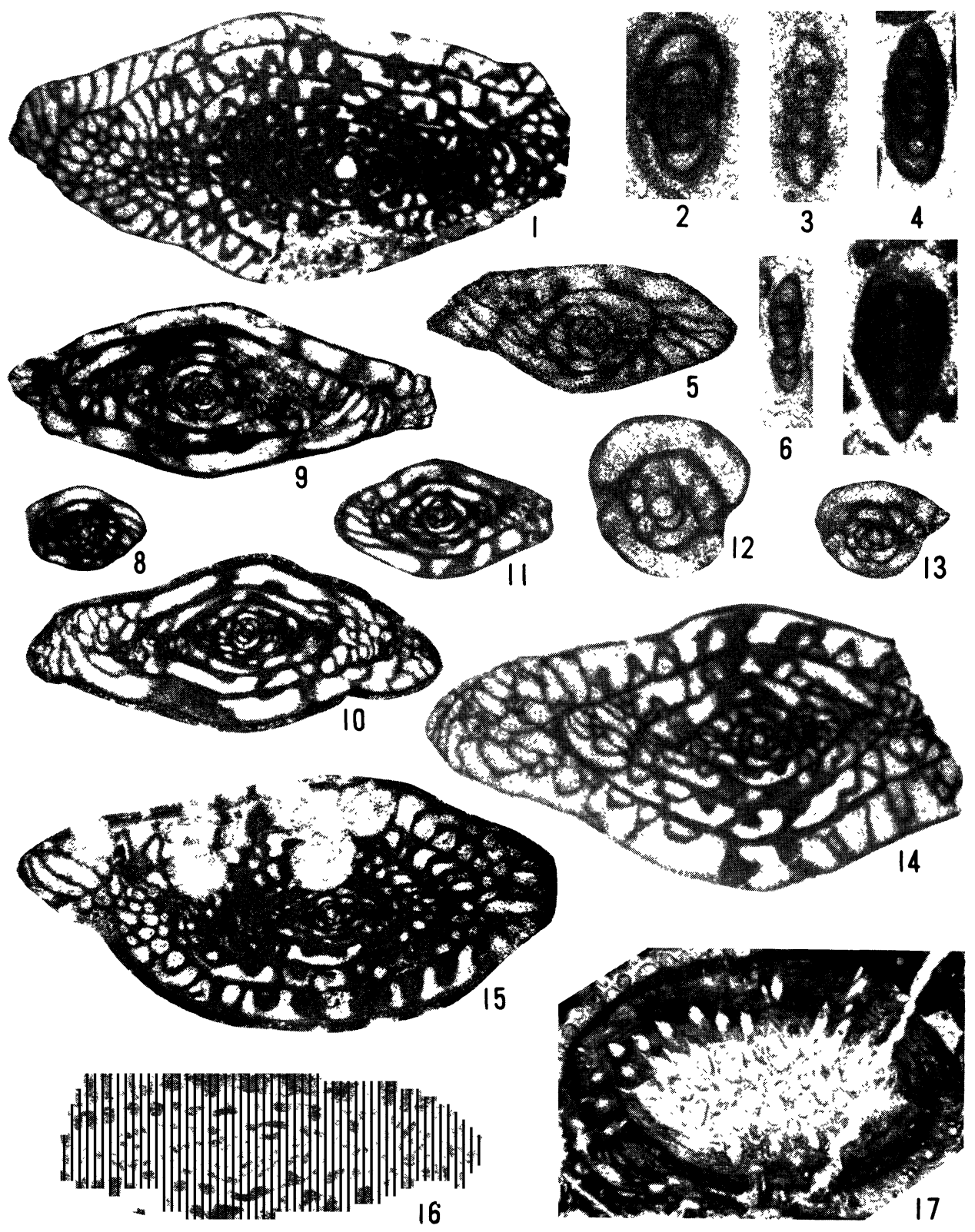

Fig. 3. Some fusulines and bryozoans from the limestone pebbles. 1: Beedeina higoensis, $\times 15.2$ : Eostaffella akiyoshiensis, $\times 60$. 3: Millerella sp. cf. M. marblensis, $\times 60$. 4: Eostaffela etoi, $\times 60$. 5: Eoschubertella lata, $\times 60$. 6: Pseudonovella carbonica, $\times 60$. 7: Ozawainella mosquensis, $\times 60$. 8: Fusulinella minutissima, $\times 25$. 9, 10: Fusulinella elegantula, $\times 25$. 11: Fusulinella pygmaea, $\times 25$. 12 : Eoschubertella toriyamai, $\times 60$. 13: Eoschubertella obscula, $\times 60$. 14: Beedeina lanceolata, $\times 25$. 15: Fusulina sp. cf. kanmerai, $\times 25$. 16: Fusulina sp. cf. $F$. shikokuensis, $\times 25$. 17: Girtypora sp. cf. G. sakagamii, $\times 15$. 
conglomerate was initially accumulated around the seamount during the early Middle Permian (the lower part of the Parafusulina zone), however, because the Takaoka Formation is considered to be the Jurassic, the present conglomerate should be exotic block.

Finally, we would like to express our sincere gratitude to Dr. Teiichi Kobayashi, M. J. A., Professor Emeritus of the University of Tokyo for his continuous guidance and encouragement and to Professor Hisayoshi Igo of Tsukuba University for his kind identification of conodonts. We are also indebted to Messrs. Tetsuya Kawabe and Yutaka Tanaka for their kind assistance in collecting samples. The present study is financially supported by the Grantin-Aid for Scientific Research from the Japan Academy.

\section{References}

Ishii, K. (1958) : Fusulinids from the middle Upper Carboniferous Itadiorigawa Group in western Shikoku, Japan. Part I. Genus Fusulina. Jour. Inst. Polytech. Osaka City Univ., ser. G, 4, 1-18, pls. 1-5.

(1961) : ditto. Part III. Stratigraphy and concluding remarks. ibid., 5, 31-52.

(1962) : ditto. Part II. Genus Fusulinella and other fusulinids. Jour. Geosci. Osaka City Univ., 6, 1-43, pls. 1-12.

Isozaki, Y. (1985) : Yasuba conglomerate and its mode of occurrence. Jour. Geol. Soc. Japan, $91(8)$, 535-551, pl. 1.

Katto, J. (ed.) (1982) : Explanatory text of the geological map of Sakawa town (scale $1: 25,000$ and $1: 50,000)$. Naigaichizu Co. Ltd., $37 \mathrm{pp}$.

Kobayashi, T. (1950) : Regional Geology of Japan, Shikoku Province. Asakura-Shoten, $243 \mathrm{pp}$.

Sugimura, A. (1985): A new Carboniferous species of Girtypora (Bryozoa) from the Akiyoshi Limestone Group, southwest Japan. Bull. Akiyoshi-dai Mus. Nat. Hist., no. 20 , pp. 17-23, pl. 7 .

Toriyama, R. (1945): The fusulinids in the limestone conglomerate of Inomine in the province of Tosa. Jap. Jour. Geol. Geogr., $20(1), 1-11$, pl. 1. 